most of which come under this category, and each may contain relevant information. About 1,000 entomological journals are held by the Natural History Museum's entomology library, but only 65 are covered by the expanded Science Citation Index (SCI). Because some 93 per cent of potentially relevant journals are not considered, it is good luck rather than a sign of good quality to be included in the SCI.

The impact factor is a powerful and welcome tool in some disciplines. In basic biodiversity research, however, it is not applicable. Qualified referees must evaluate the scientific work itself.

Frank-Thorsten Krell

Entomology Department, Natural History Museum, Cromwell Road, London SW3 5BD, UK

\section{We have moral authority to apologize for the past}

Sir - Your editorial "Hollow apologies should be avoided" (Nature 403, 813; 2000) noted that Hubert Markl, president of the Max Planck Society (MPS), "is right to resist pressure to apologize" for the participation of German scientists in Nazi experiments.

Subsequently, Bernd Wirsing of the MPS wrote (Nature 404, 222; 2000) that "President Markl has already publicly apologized", although reference to the MPS website reveals that this apology is weakened somewhat by circumlocutory equivocation. The issue of apology by proxy remains relevant in this context and in others.

The Pope and President Wahid of Indonesia have recently apologized for the sins and crimes of their predecessors, but the Australian prime minister, John Howard, has consistently refused to apologize to Aboriginal Australians for generations of abuse and neglect by governments. Howard's rationale is much the same as that put forward in Nature's editorial: the successors of those who committed crimes in the past do not have the moral authority to apologize on their behalf.

Such caution is mistaken. Consider an analogy: if one were enfeebled or incapacitated, it would be reasonable to place one's affairs in the hands of an attorney who would then assume one's legal powers and exercise them in one's stead for one's good.

Markl is the president of the organization that fully took over the members of its predecessor, the Kaiser Wilhelm Society, under whose auspices experiments on human beings took place. Markl is in the position of acting for a morally incapable predecessor. The Kaiser Wilhelm Society was morally deficient in using children and other Nazi victims in its experiments. Recalcitrant members might well refuse to acknowledge the wrongfulness of their actions or to ask for forgiveness. So indeed, might many of our forebears and contemporaries in this country.

But the MPS and Australia's leaders are not deficient in that respect. They can act as the rightful exercisers of moral authority here, and they ought to do so precisely on the grounds that Markl advances: that those who performed experiments on humans or so egregiously treated Aborigines were deficient in their moral understanding and certainly incapacitated from making a genuine apology.

Finally, it is wrong to argue that an apology needs to be made only to the survivors of atrocious policies and practices. It surely needs to be made to all the descendants of those who were affected - survivors or the murdered - and to the rest of humanity. Damian Grace ${ }^{\star}$, John Carmody $\dagger$

${ }^{\star}$ Faculty of Arts and Social Sciences, $\uparrow$ Faculty of Medicine, University of New South Wales, Sydney, New South Wales 2052, Australia

\section{Offside researchers score an own goal}

Sir - In an astounding analysis of the failure of assistant referees to judge offside situations correctly (R. D. R. Oudejans et al. Nature 404,$33 ; 2000$ ), a group of soccer scientists from - almost inevitably - the Netherlands define the object of their study thus: "In football (soccer), a player is 'offside' if he or she is closer to the goal than the last defender (excluding the goalkeeper) when the ball is passed to them."

However, 'offside' in football depends on an attacker's distance from the goal line (the line forming the boundary of the pitch on that side, on which the defending team's goal is placed) rather than from the goal itself. Moreover, with respect to the offside rule the goalkeeper has the same status as any other player. Could it be that, in reality, assistant referees err so often because they don't know the rules of the game any better than those who conduct scientific studies on the rules?

For the correct rule see http://www. fifa2.com/scripts/runisa.dll?s7.6750696:gp: 919357:67173+refs/laws/law11 — or ask somebody in the nearest pub.

Winfried S. Peters ${ }^{\star}$, Bernd Herkner $\dagger$, Alex Webb $\ddagger$, Julian Hibberd $\ddagger$

${ }^{*}$ Kinematic Cell Research Group,

Goethe University Biocentre, Marie-Curie-Strasse 9, D-60439 Frankfurt am Main, Germany

$\dagger$ State Museum of Natural History, Erbprinzenstrasse 13, D-76133 Karlsruhe,

Germany

$\$$ Department of Plant Sciences, Downing Street, Cambridge CB2 3EA, UK

\section{Let Armenia show why it's the place for Sesame}

Sir - Organizers of the proposed new research centre for the Middle East, Caucases, Mediterranean and Gulf region, which will be based around the Sesame synchrotron, are saying it will be built in Jordan (Nature 404, 798; 2000). But the decision has not yet been officially made and at the Interim Council meeting in Geneva, on 10 and 11 April, both Jordan and Armenia were chosen as likely sites.

I believe it is a violation of fair and objective selection practices for organizers of such an important international site to show this bias towards Jordan before the final decision has been made.

As chairman of the Armenian Committee for Sesame, established by the Republic of Armenia, I suggest that an independent panel of accelerator experts from around the world should visit both sites. They could then make an evaluation on the basis of each country's technical expertise and government commitment, and assess which offers the quickest and most economical way to make the project operational.

Armenia and Jordan have submitted their list of advantages. Let the independent panel review each item carefully and make their recommendation to the Sesame Interim Council and to Unesco. The birth of an international centre such as Sesame deserves this careful and fair process. For more information, please visit our website at www. natureswonder. com/sesame.

J.S. Hovnanian

J. S. Hovnanian and Sons, Mount Laurel, New Jersey 08054, USA

\section{Giving Arabs credit for Persian works (again)}

Sir - I'm afraid the Book Review of JeanLuc Chabert's A History of Algorithms (Nature 403, 703; 2000) contains the same frequently made mistake pointed out by your correspondent $\mathrm{S}$. Khochbin (Nature $405,14 ; 2000)$ in another recent article.

The reviewer includes the Persian mathematician and scholar Nasir al-Din al-Tusi among Arab mathematicians. Nasir al-Din al-Tusi did write in Arabic (as well as Persian), but this is like saying Sir Isaac Newton was not English, because he wrote in Latin!

Nasir al-Din al-Tusi was born in Tus, a city in the northeast part of Iran, in the province of Khorasan, quite far from any Arab populations at the time, or even now. Payman Arabshahi

Jet Propulsion Laboratory, California Institute of Technology, 4800 Oak Grove Drive, MS 238-343, Pasadena, California 91109, USA 